\title{
Kota Baru: Kajian Awal Tentang Kawasan Di Yogyakarta
}

Surayati Supangat

Rita M. Setianingsih

Keywords: settlement, indis, architecture, colonial, history, spatial

\section{How to Cite:}

Supangat, S., \& Setianingsih, R. M. Kota Baru: Kajian Awal Tentang Kawasan Di Yogyakarta. Berkala Arkeologi, 15(3), 180-184. https:// doi.org/10.30883/jba.v15i3.692

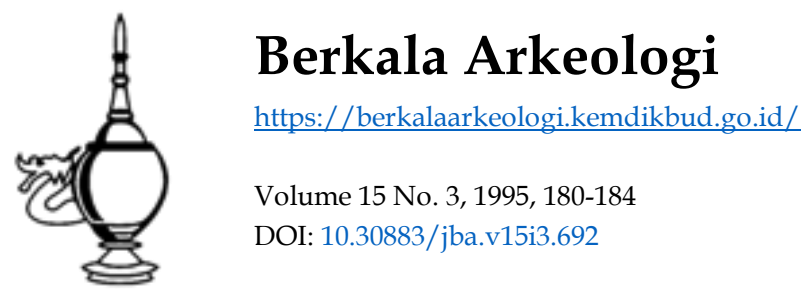

\section{(c) (i) (2)}

This work is licensed under a Creative Commons Attribution-NonCommercialShareAlike 4.0 International License. 


\title{
KOTA BARU: \\ KAJIAN AWAL TENTANG KAWASAN DI YOGYAKARTA
}

\author{
Surayati Supangat \& Rita M Setianingsih \\ (Suaka PSP Provinsi DI Yogyakarta)
}

\section{Latar Belakang}

Dalam rangka partisipasi Seminar tentang "Manusia Dalam Ruang: Studi Kawasan Dalam Arkeologi" dicoba untuk mengemukakan secara singkat tentang pemukiman orang-orang Belanda dan makalah ini merupakan studi awal berdasarkan atas pengamatan langsung ke lapangan dan data pustaka.

Pemilihan judul makalah dilandasi suatu pemikiran bahwa kawasan Kota Baru sebagai bekas pemukiman orang-orang Belanda merupakan sisa kehidupan masa lampau yang mempunyai nilai yang amat penting bagi pengetahuan. Di samping penting bagi ilmu pengetahuan kondisi kawasan Kota Baru cukup "rawan", apabila tidak dipikirkan pelestariannya dalam waktu dekat akan terancam identitasnya

Pada awal abad ke 20 dibuka "perkampungan" orang Eropa yang terletak di sebelah Utara kota Yogyakarta, yang sekarang dikenal sebagai Kota Baru. Perkampungan itu merupakan perluasan kota Yogyakarta bagi orang-orang Eropa, yang sebelumnya untuk pertamakali besmukim di kawasan sebelah timur benteng Kompeni (Vredeburg). Pemukiman pertama itu belakangan juga meluas ke sebelah timur Sungai Code, dan sekarang dikenal sebagai Bintaran.

Tinibulnya pemukiman-pemukiman tersebut di atas tidak lepas dengan keberadaan Kraton, kota Yogyakarta, Vredeburg, pasar dan Kepatihan. Pada mulanya pemukiman orang Eropa itu diperuntukkan bagi perwira-perwira pasukan Kerajaan Belanda yang setelah pensiun beralih menjadi pengusaha, umumnya mengusahakan perkebunan (tebu). Sesudah tahun 1870 di bagian seiatan dan barat kota Yogyakarta terdapat pabrik gula milik orang Belanda.

Berdirinya pabrik gula juga disebabkan karena pada awal abad ke sembilanbelas, kaum bangsawan istana mulai ada yang menyewakan tanah jabatannya (lungguh atau appanage) kepada orang asing untuk dijadikan perkebunan. Tanaman yang banyak diusahakan pada saat itu umumnya tebu.

Jaringan transportasi dipermudah dengan dioperasikannya rel kereta api NIS (Nederlandsch-Indische Spoonwegmaatschappij) pada tahun 1872, antara Yogya - Semarang, yang stasiunnya berada di Lempuyangan (tidak jauh dari Kota Baru, atau mungkin dahulu masuk ling- kungan Kota Baru). NIS juga meluas ke daerahdaerah di sekitar Yogyakarta, seperti Ngabean, Srandakan, Brosot, Beran, Medari, Cebongan dan daerah Selatan Yogya seperti Pundong dan Plered.

\section{Kota Baru}

Secara administratif kawasan Kota Baru termasuk dalam Kalurahan Kota Baru Kecamatan Gondokusuman, Kotamadya Yogyakara Pemukiman itu berinteraksi dengan adanya perkebunan di sekitar kota Yogyakarta.

Keberadaan kota Baru sebagai pemukiman orang-orang Belanda tidak terlepas dari tata kehidupan kota Yogyakarta antara tahun 1850 - 1900 Mesehi. Dalam kurun waktu tersebut situasi dan kondisi Kasultanan Yogyakarta mengalami penggeseran terutama dalam bidang politik. Dampak yang timbul adalak perkembangan di bidang ekonomi makin meningkat yang banyak mendatangkan keuntungan bagi Bangsa Belanda. Penguasa Belanda dalam kurun waktu tersebut memberi peluang besar-besaran kepada penguasa swasta untuk membuka usaha di Yogyakarta. Bidang usaha itu antara lain adalah asuransi, ja-sa transportasi Kereta Api, perkebunan dan $\mathrm{Pa}$ brik Gula. Aktifitas ekonomi penghuninya mempercepat pertumbuhan kawasan tersebut.

Sejak awal pertumbuhannya, Kota Baru memiliki beberapa faktor yang erat berkaitan dengan sebuah tata perkotaan. Ujud fisik dari faktor dimaksud antara lain adalah:

- kapel dan seminari (faktor religi)

- AMS, MULO, Seminari (faktor pendidikan)

- Petronella Hospitaal dan DAT Hospitaal (faktor kesehatan)

- Sport Terrein dan Race Terrein/lapangan pacuan (faktor amusement)

- Asrama Polisi (faktor keamanan)

- Sarana jalan dan selokan/riool (faktor transportasi dan sanitasi/kesehatan kota).

Keseluruhannya memang tampak dirancang secara rapi dengan jaringan jalan yang teratur dimana bangunan di kanan-kirinya berderet berhadapan.

Berikut ini adalah beberapa karya arsitektur yang memiliki nilai sejarah dan arsitektur yang mewarnai kawasan Kota Baru.

1. SMA BOPKRI I (di jalan Wardhani) 
Jaman Belanda : Christelijk MULO

Jaman Jepang : tangsi militer

Jaman Revolusi : Pusat Pendidikan Militer dan

Sekolah Kadet

2. Asrama Kompi ABRI/TNI AD (di jalan Wardhani)

Jaman Belanda : asrama polisi

Jaman Jepang : Kido-Butai (gudang senjata) dan markas tentara

3. PUSKAT/STF Pradnya Widya (di jalan Abu Bakar Ali)

Jaman Belanda : seminari

Jaman Jepang : kantor Kochi

Jaman Revolusi: Kantor Kementerian Pertahanan dan Kantor Kementerian Sosial

Catatan: pada dinding di sisi selatan bangunan induknya terdapat "prasasti" yang bertuliskan

ARCH. EN : INGR BUR

FERMONT - CUYPERS

4. SMA 3 (di jalan Yos Sudarso)

Jaman Belanda: AMS (Algemeene Middelbare

School) bagian $B$

Jaman setelah Revolusi: penampungan Pelajar

Pejuang

5. SMP 5 (di jalan Juwadi)

Jaman Belanda : MULO

Sebelum Clash II : asrama Militer Akademi

6. Gedung Asuransi Jiwa Sraya (di jalan Faridan M Noto)

Jaman Beianda : rumah pejabat Nellmij

Jaman Jepang: rumah perwira militer Jepang

(Mayor Otsuka)

Jaman Revolusi: tempat perundingan perlucutan senjata Jepang (tanggal 7 Oktober 1945)

7. Kantor Departemen Transmigrasi (di jalan Suroto)

Jaman Belanda : rumah tempat tinggal

Jaman Revolusi : tempat berakhirnya Route

Gerilya

Panglima Besar Jenderal Sudirman (ada prasasti pendek

bertuliskan 10 Juli 1949)

Catatan : di bagian dalam bangunan (tempat tinggal) itu terdapat sebuah bar, yakni ruangan minum

8. DKT/Rumah Sakit Tentara (di jalan Juwadi)

Jaman Belanda : DAT Hospital (berdiri tahun 1931)

Jaman Jepang : rumah sakit
9. Stasiun Lempuyangan (di Pengok)

Bangunan yang tidak pernah berubah fungsi sejak pertama digunakan pada tahun 1872 .

10. Rumah Sakit Bethesda (di jalan Jenderal Sudirman).

Sejak masih bernama Petronella Hospital, hingga kini dikenal sebagai Rumah Sakit Bethesda, demikian itulah pemanfaatan gedung megah di sudut timurlaut kawasan Kota Baru

11. RRI (di jalan Ahmad Jajuli)

Pada jaman Revolusi, bangunan tersebut adalah tempat tinggal dokter Yap

\section{Kridosono}

Pada jaman Belanda digunakan untuk Spor! Terrein (Lapangan Olahraga).

\section{Kota Baru dalam perbandingan}

Secara umum bangunan dan rumah tempat tinggal di Kota Baru jelas berciri arsitektur koicnial. Seperti bangunan permukıman Eropa yang didirikan di kota-kota besar lainnya di pulau Jawa, maka dapat dikatakan bahwa poia penyusunan pembangunan kawasan Kota Baru tidak jauh berbeda

Di Jakarta, upaya pemenuhan kebutuhan akan permukiman bagi orang Eropa di bumi jajanannya, pada masa-masa menjelang abad ke duapuluh ditandai dengan pembangunan kawasan Menteng, sedangkan Surabaya memilih lokasi yang sekarang dikenal sebagai daerah Darmo

Berkenaan dengan gaya hidup yang dımılikı calon pemakainya, permukiman di tempat-tempat dimaksud juga dipersiapkan dengan menerapkan konsep tatakota yang begitu dikenal perancangnya. Sebagaimana yang juga dapat dilina: ot kawasan Darmo dan Menteng. konsep cukup kiasik Eropa tampak melalui sumbu-sumbu dibelah jalan, boulevard dan taman. Taman difungsikaan tidak hanya sebagai alat penghijauan melaınkan disertakan pula kemampuannya sebagai sarana olahraga. Kenampakan akan pemikiran Eropa dalam pembentukan kawasan itu juga nyata dari pembuatan jalan-jalan yang tidak mengikuti arah mata angin (Yulianto Sumalyo,1993:18). Di kawasan Kota Baru -pun, jalan ditata tanpa mempermasalahkan arah mata angin.

Pada masanya, ada pula tokoh yang begitu dikenal sebagai "penghasıl" karya-karya arsitektur di berbagai "kawasan Eropa" di kota-kota besar di pulau Jawa. Arsitek besar akhir abad ke sembilan belas - awal abad ke duapuluh yang mampu menuangkan konsep-konsep arsitektur Eropa justru di kawasan tropis itu adaiah Ed. 
Cuypers. la diketahui pernah mendirikan Architecten Bureau Ed. Cuypers \& Hulswit. Karya-karyanya yang masih dapat dikenali, tersebar tidak hanya di Jakarta atau Bandung, melainkan pula di Semarang dan Surabaya (Yulianto Sumalyo, 1993:137). Yogyakarta rupa-rupanya juga salah satu kota yang memanfaatkan keahlian arsitek tersebut untuk mengisi kawasan Kota Baru. Bangunan PUSKAT/STF Pradnya Widya, seperti yang ditandai oleh "prasasti pendek" di sana, bersama-sama dengan karya arsitektur lain dari Ed.Cuypers di berbagai kota, adalah bukti betapa kawasan demikian memang betul-betul disiapkan untuk mampu menghadirkan suasana "kemegahan" Eropa.

Kesan demikian akan sama di beberapa kawasan sejenis. Bangunan tempat tinggal di Kota Baru, Menteng, atau Darmo mesti memiliki pembagian ruangan yang cukup banyak dan dilengkapi dengan dengan bar. Teras dan pilaster adalah unsur bangunan yang juga harus ada. Demikian pula dengan jendela dan pintu krepyak.

Adapun perbedaan yang terlihat bila berkenaan dengan status sosial penghuninya, lebih ditonjolkan pada ukuran besar-kecilnya bangunan.

\section{Penutup}

Kajian awal tentang kawasan Kota Baru ini dimaksudkan untuk mencoba mengenali berbagai aspek yang berkenaan dengan sosialisasi konsep pelestarian atas berbagai bentuk bangunan berciri kolonial di Yogyakarta. Seperti halnya dengan yang telah dikerjakan terhadap kawasan Kebayoran Baru dan Menteng di Jakarta yang telah berlangsung sejak tahun 1972 dan 1975.

Tujuan daripada pelestarian itu sendiri bukan untuk mengagungkan kolonialisme tetapi justru mengunggulkan hal-hal positip yang dapat dicerna dan terkondisi sepanjang sejarahnya. Selain itu, upaya pelestariannya dikaitkan dengan berbagai kepentingan praktis yang berhubungan dengan pengkayaan budaya maupun ekonomi. Sebagaimana diketahui, kawasan Kota Baru tentu menyimpan kekuatan yang cukup besar dalam upaya pembentukan jati diri masyarakatnya sebagai bagian dari pembentukan jati diri bangsa.

Upaya pelestarian yang didasari dengan pengenalan berbagai aspek pendukung dan penghalangnya diarahkan sekaligus untuk penciptaan kawasan yang patut diwariskan pada generasi mendatang dan juga marketable di dunia kepariwisataan. Begitu banyak hal yang masih menunggu untuk disoroti, dan disadari pula bahwa kerja yang multidisiplin saja yang dapat menanganinya. Begitu kecil yang mampu disodorkan dalam tulisan ini, dan sebaliknya begitu besar yang diharapkan sebagai masukan dalam kesempatan ini. Terima kasih.

\section{KEPUSTAKAAN}

\section{Gegevens Djokjakarta 1925}

1993 Keputusan Gubernur Kepala Daerah Khusus lbukota Jakarta Nomor:475 tahun 1993. Jakarta:Dinas Tata Bangunan dan Pemugaran 1993.

1993 Keputusan Gubernur Kepala Daerah Khusus lbukota Tentang Kebayoran Baru. Jakarta: Dinas Tata Bangunan dan Pemugaran 1993

1993 Keputusan Gubernur Kepala Daerah Khusus Ibukota Tentang Menteng Jakarta: Dinas Tata Bangunan dan Pemugaran 1993.

Rencana Pelestarian dan Pengembangan Benteng Vredeburg, buku I dan II. Yogyakarta : Universitas Gadjah Mada.

Soedarisman, Poerwokeosoemo,.1984, Daerah Istimewa Yogyakarta, Yogyakarta: Gadjah Mada University Press.

Yulianto Sumalyo. Arsitektur Kolonial Belanda Di Indonesia. Yogyakarta: Gadjah Mada University Press, 1993. 


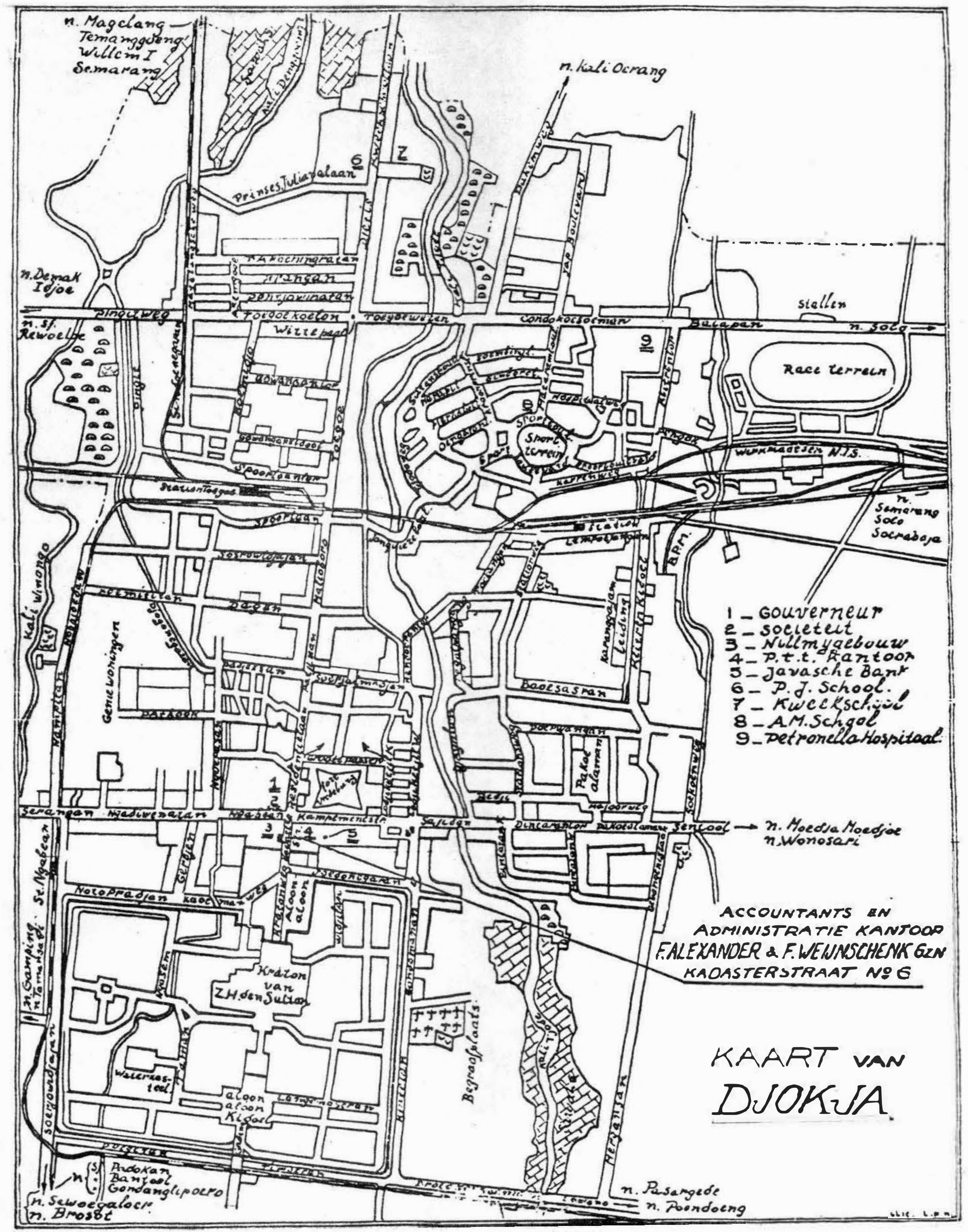

Diambil dari Moo1 Jogjakarta $193 E$ 
- 